\title{
Author Correction: Cellular census of human fibrosis defines functionally distinct stromal cell types and states
}

Thomas B. Layton, Lynn Williams, Fiona McCann (1), Mingjun Zhang (1), Marco Fritzsche, Huw Colin-York, Marisa Cabrita, Michael T. H. Ng D , Marc Feldmann, Stephen N. Sansom (D), Dominic Furniss (D), Weilin Xie \& Jagdeep Nanchahal (D)

Correction to: Nature Communications https://doi.org/10.1038/s41467-020-16264-y, published online 2 June 2020.

The original version of this Article contained an error in the spelling of the authors Stephen N. Sansom and Marco Fritzsche, which were incorrectly given as Stephen Samson and Marco Fritszche. This has now been corrected in both the PDF and HTML versions of the Article.

Published online: 24 June 2020

\footnotetext{
(c) (i) Open Access This article is licensed under a Creative Commons Attribution 4.0 International License, which permits use, sharing, adaptation, distribution and reproduction in any medium or format, as long as you give appropriate credit to the original author(s) and the source, provide a link to the Creative Commons license, and indicate if changes were made. The images or other third party material in this article are included in the article's Creative Commons license, unless indicated otherwise in a credit line to the material. If material is not included in the article's Creative Commons license and your intended use is not permitted by statutory regulation or exceeds the permitted use, you will need to obtain permission directly from the copyright holder. To view a copy of this license, visit http://creativecommons.org/licenses/by/4.0/.
}

(C) The Author(s) 2020 